\title{
Analysis of Genotype x Environment Interaction for Grain Yield in Maize Hybrids
}

\author{
F. Nzuve ${ }^{1}$, S. Githiri ${ }^{2}$, D. M. Mukunya ${ }^{1} \&$ J. Gethi ${ }^{3}$ \\ ${ }^{1}$ Department of Plant Science and Crop Protection, University of Nairobi, Nairobi, Kenya \\ ${ }^{2}$ Jomo Kenyatta University of Agriculture and Technology, Nairobi, Kenya \\ ${ }^{3}$ Seed Systems, CIMMYT - Southern Africa, Mt Pleasant, $12.5 \mathrm{~km}$ peg Mazowe Road, Harare, Zimbabwe \\ Correspondence: F. Nzuve, Department of Plant Science and Crop Protection, University of Nairobi, P. O. Box \\ 29053-0625, Nairobi, Kenya. E-mail: felistermusembi@gmail.com
}

Received: July 19, 2013 Accepted: August 26, 2013 Online Published: October 15, 2013

doi:10.5539/jas.v5n11p75 URL: http://dx.doi.org/10.5539/jas.v5n11p75

\begin{abstract}
Maize is an important staple crop for millions of people in Sub-Saharan Africa. The crop grows in a wide range of environmental conditions. The present study was performed to analyze the genotype-by-environment $(\mathrm{G} \times \mathrm{E})$ interaction for grain yield of fourty two single cross hybrids grown in three environments located at different agro-ecological zones of Kenya. The maize genotypes were grown in randomized complete block design with three replicates in 2006 and 2007. Grain yield data of the single cross hybrids was analysed using the additive main effects and multiplicative interaction (AMMI) and GGE biplot methods. The additive main effects and multiplicative interaction model (AMMI) analysis of variance (additive main effects) showed significant effects for genotypes, environment and the genotype by environment interaction. The total proportion contributed by environment and G x E interaction accounted for $78 \%$ and $10 \%$ of the total variation. The results also showed that $64.5 \%$ of the total variation was contributed by the environment while the genotype and interaction was associated with $20.7 \%$ and $10.3 \%$ of the total variation, respectively. The most stable genotype in the high yielding group in this study was CML312/TZMI 711 (X20), followed by genotypes TZMI 102/CML384 (designated as X33), and CML312/TZMI 712 (X21). The genotype CML312/TZMI 711 (designated as X20) could be used for broad selection since it was found to be the most ideal genotypes with both high mean yield and high stability. In the biplot analysis, X20 was also close to the origin, had the shortest vector from the ATC and with large PC1 scores (high mean yield) and small (absolute) PC2 scores (high stability) implying it had the least contribution to genotype by environment interaction (GEI). Through the stability analysis, the superior genotypes identified could also be used as references for genotype evaluation and also included in further testing in both early and later stages of selection.
\end{abstract}

\section{Introduction}

Maize is an important staple crop for millions of people in Sub-Saharan Africa (Sibiya et al., 2011). The application of quantitative genetics in maize breeding enables the development of superior genotypes whose genetic parameters have been estimated thus maximizing the gains from selection (Vieira et al., 2012). This also enables the identification of pleiotrophic effects which largely contribute to the genotypic variation with regard to quantitative traits (Wisser et al., 2011). The maize genotype possesses different kinds of gene actions that interact differently in the inheritance of the various plant attributes. Maize crop also grows on a wide range of environmental conditions with regard to water balance, solar radiation, and temperatures (Hill et al., 1997). This differential response of maize germplasm to these varied agro ecological zones (AEZ) contributes to the genotype by environment interaction (GEI) which often hampers the identification of high yielding and stable maize hybrids (Akcura et al., 2011). The GEI interaction variance can be controlled by increasing the number of test environments.

The GEI makes genotypes to perform differently in different environments especially in the stress prone Sub Saharan Africa (SSA) with highly variable weather conditions (Sibiya et al., 2011). This has complicated the breeding and selection for important traits due to cross interaction among the hybrid ranks in different environments (Carson et al., 2002; Beyene et al., 2011; Mitrovic et al., 2012). Thus, promising genotypes with wide adaptation are barely selected. The GE components contribute to noise reducing the heritability of the traits 
affecting breeding progress due to inaccurate selections especially in single environments. Through GEI studies, stable genotypes which are adapted to specific target areas and potential candidates for promising hybrid combinations could be identified (Abay et al., 2009). The identification of stable maize varieties (the response of crosses across several environments) could help to enhance the farmers' acceptability or adoption of elite new varieties since the stable maize genotypes tend to utilize the resources in higher performing environments to produce above average maize varieties in all the environments (Jong and Brewbaker, 2005).

The GEI analysis has been performed using different methods, such as, stability analysis following additive main effects and multiplicative interaction model (AMMI), principal component analysis and linear regression analysis, analysis of variance (ANOVA) and GGE biplot analysis (Abay et al., 2009; Miranda et al., 2009; Akcura et al., 2011; Mitrovic et al., 2012). The ANOVA explains only main effects and gives no information on individual genotypes and localities which are components of the interaction (Mitrovic et al., 2012). The AMMI allows for large set of technical interpretations and uses a principal component (autovector) to interpret cultivar performance by integrating the use of ANOVA and PCA. The AMMI analyses combine additive components in a single model for the main effects of genotype and environment as well as multiplicative components for the interaction effect. The graphic analyses bring out phenotypic stability, genotypic behavior of the cultivars and environments which optimize performance (Miranda et al., 2009). The AMMI model displays main effects of genotypes and environment and their interactions. It also estimates the genotype responses and separates noise from real sources of variation through partitioning of the GEI. It also contributes to improved cultivar evaluation, recommendations and selection of test sites (Abay et al., 2009). It is useful in summarizing and approximating patterns of response which exist in the original data (Akcura et al., 2011). The GGE biplot analysis is another method which integrates the genotype and genotype by environment effects in the evaluation of cultivars. The GGE which uses graphic axes identifies superior cultivars in the mega environments (Akcura et al., 2011). Mega environments comprise groups of locations which consistently share the same test cultivars (Abay et al., 2009). It also combines ANOVA and PCA by partitioning together sum of squares of genotypes and sum of squares of genotype by environment interaction using the PCA method. It is also used for the presentation and estimation of genotypes in different environments (Miranda et al., 2009).

Given the importance of maize in Kenya and the SSA, there is need for increased maize production in order to ensure food security and also contribute to national development. The growing of high yielding and stable maize varieties will help to increase maize production and lead to improved living standards. Thus this study set out to a) to examine the yield and yield stability of single cross hybrids in three environments found in different agro-ecological environments in Kenya using (additive main effects and multiplicative interaction) AMMI and GGE biplot method b) to identify the genotypes, which could have wide or specific adaptation using the GGE biplot analysis method.

\section{Materials and Methods}

\subsection{Introduction}

The maize genotypes comprised fourty two single cross hybrids developed from seven inbred lines crossed in a full diallel. The inbred lines included CML 204, CML 312, CML 373 and CML 384 from CIMMYT (Table 1a). The rest of the inbred lines included TZMI 102, TZMI 711 and TZMI 712 from IITA (Table 1b). The maize genotypes were evaluated for grain yield performance at three sites; Kenya Agricultural Research Institute (KARI), Kiboko, University of Nairobi's Kabete Field Station and KARI-Kakamega (Table 2). 
Table 1(a). The description of the CIMMYT germplasm used in the study

\begin{tabular}{|c|c|c|c|c|}
\hline Inbred lines & Pedigree & Adaptation & $\begin{array}{l}\text { Heterotic } \\
\text { Group }\end{array}$ & Important Traits \\
\hline CML 204 & $\begin{array}{l}\text { [7794]-SELF-4-1- } \\
\text { S9-1-4-7-4-5-BB. }\end{array}$ & $\begin{array}{l}\text { Mid altitude and semitropical } \\
\text { areas of Africa }\end{array}$ & Group B & $\begin{array}{l}\text { Long late maturing inbred line } \\
\text { It has white grains and a dent texture. } \\
\text { Good tolerance to MSV and rust }\end{array}$ \\
\hline CML 312 & $\begin{array}{l}\text { S89500F2-2-2-1-1- } \\
\text { B*5. }\end{array}$ & Sub-tropical areas & Group A & $\begin{array}{l}\text { Tall intermediate maturing inbred line with white semi flint kernel } \\
\text { Good resistance to GLS and E. turcicum }\end{array}$ \\
\hline CML 373 & $\begin{array}{l}\text { P43SR-4'1-1-2-1-B- } \\
\text { 8-1-BBB }\end{array}$ & $\begin{array}{l}\text { Adapted to the subtropical } \\
\text { areas }\end{array}$ & Group A & $\begin{array}{l}\text { It has white flint textured kernels with intermediate maturity } \\
\text { It is a tall inbred } \\
\text { Susceptible to rust, E. turcicum and ear rot }\end{array}$ \\
\hline CML 384 & & P502C1\#-771-2-2-1-3-B & Group B & $\begin{array}{l}\text { This is a flint textured, white grained inbred line } \\
\text { It is a tall late maturing inbred line with good resistance to ear rot and rust }\end{array}$ \\
\hline
\end{tabular}

Source Pswarayi and Vivek, 2004

Table 1(b). The description of the IITA germplasm used in the study

\begin{tabular}{llll}
\hline Inbred line & Parentage & Heterotic group & Remarks \\
\hline TZMI 711 & $\begin{array}{l}\text { National-1 variety crossed to an } \\
\text { IITA MSV-resistant population, } \\
\text { TZSR }\end{array}$ & B & $\begin{array}{l}\text { TZSR was developed through intercrossing four populations namely TZB, TZPB, } \\
\text { POP 21, and POP 22 }\end{array}$ \\
TZMI 712 & $\begin{array}{l}\text { A mid-altitude inbred line TZMI } \\
\text { 501 from IITA crossed to an inbred } \\
\text { line ZSR 923 S4 bulk, from }\end{array}$ & B & \\
& $\begin{array}{l}\text { CIMMYT } \\
\text { Its pedigree is CamInb.TCSel1-13- } \\
\text { TZMI 102 } 1 \text { B } 1 \text { - B }\end{array}$ & & $\begin{array}{l}\text { TZMI 102 was a parent of the best single-cross hybrid marketed in Plateau State } \\
\text { of Nigeria as '8535-23' }\end{array}$ \\
\hline
\end{tabular}

Source: Menkir and Adepoju, 2005

Table 2. Agro-climatic description of the three experimental sites used in the study

\begin{tabular}{|c|c|c|c|c|c|c|c|}
\hline \multirow[t]{2}{*}{ Site } & \multicolumn{3}{|c|}{ Geographic position } & \multirow{2}{*}{$\begin{array}{l}\text { Mean annual } \\
\text { Rainfall }(\mathrm{mm})\end{array}$} & \multicolumn{2}{|c|}{ Temperature $\left(0^{\circ} \mathrm{C}\right)$} & \multirow[t]{2}{*}{ Soil type } \\
\hline & Longitude & Latitude & Altitude & & Min & Max & \\
\hline $\begin{array}{l}\text { KARI, Kiboko } \\
\text { (Agro-ecological zone 5) }\end{array}$ & $37^{\circ} 75 \mathrm{E}$ & $2^{\circ} 15^{\prime} \mathrm{S}$ & $993 \mathrm{~m}$ & $548 \mathrm{~mm}$ & 17 & 30.6 & $\begin{array}{l}\text { Ferrasols to ferric luvisol on the old } \\
\text { peneplain and eutric fluvisol at the bottom } \\
\text { of the river valley }\end{array}$ \\
\hline $\begin{array}{l}\text { KARI, Kakamega } \\
\text { (Agro-ecological zone 2) }\end{array}$ & $34^{\circ} 45 \mathrm{E}$ & $0^{\circ} 16^{\circ} \mathrm{N}$ & $1585 \mathrm{~m}$ & $1995 \mathrm{~mm}$ & 13 & 28.6 & $\begin{array}{l}\text { Soils are deep, friable, Basaltic loam, } \\
\text { fertile and well drained }\end{array}$ \\
\hline $\begin{array}{l}\text { Kabete, University of Nairobi, } \\
\text { Field station (Agro Ecological } \\
\text { Zone 3) }\end{array}$ & $36^{0} 44 \mathrm{E}$ & $\mathrm{I}^{0} 15^{\prime} \mathrm{S}$ & $1820 \mathrm{~m}$ & $1000 \mathrm{~mm}$ & 16 & 23 & $\begin{array}{l}\text { Soils are well-drained, very deep, dark } \\
\text { reddish brown, friable clay with acid } \\
\text { humic top soil }\end{array}$ \\
\hline
\end{tabular}

\subsection{Diallel Crosses and Evaluation of Resulting F1 Progenies and Their Parents}

The crossing block was set up at KARI- Kiboko to generate the diallel crosses and multiply the seed population. Seven parents were sown in 13 rows each to allow for crossing with each line and have a self of each resulting to ninety-one rows. The seven parents were crossed in all possible combinations (diallel). After three weeks, weeding was done and buldock applied at the rate of $6 \mathrm{~kg} / \mathrm{ha}$ to protect the crop from maize stalk borer. Topdressing with CAN at the rate of $60 \mathrm{~kg} \mathrm{Nha}^{-1}$ was applied as a split with half applied at planting and the rest at about $10^{\mathrm{th}}$ leaf. Supplementary irrigation was also done whenever needed.

\subsection{Field Evaluation}

The single crosses generated through the diallel crosses at Kiboko were evaluated at KARI-Kiboko, Kabete Field Station and KARI-Kakamega. Fifty entries that included 42 hybrids, seven parents and commercial checks were planted. In Kabete field station and KARI Kiboko, each entry was planted in a single row while in KARI Kakamega there were two rows per entry. The rows were $5 \mathrm{~m}$ long and the plants were planted at inter- and intra-row spacings of $0.75 \mathrm{~m}$ and $0.25 \mathrm{~m}$, respectively. Between replicates, a one metre path was left to allow for easy movement during data taking. Two seeds per hill were sown and later thinned to one plant per hill. 


\subsection{Grain Yield Data Collection Among the Single Cross Hybrids}

At maturity, all the cobs in a row for each entry were harvested. The harvested cobs were then adjusted to $13 \%$ moisture content while assuming an $80 \%$ shelling percentage. The moisture content was then determined from a seed sample of ten randomly selected cobs.

\subsection{Data Analysis}

The means of all parameters recorded was done using the SAS program (SAS, 1996). The least significant differences (LSD) were used to separate these means at significance level of $5 \%$. The genotype by environment interaction was analysed using the AMMI and GGE biplot analysis embedded in the Genstat program (Genstat $14^{\text {th }}$ Edition).

i) GGE model: $Y_{i j}-\mu-\beta_{j}=\mathrm{a}_{i}+\mathrm{j}_{i j} \ldots$

ii) AMMI model: $Y_{i j}-\mu-\beta_{j}-\mathrm{a}_{i}=\mathrm{j}_{i j} \ldots$

Where $Y_{i j}$ is the measured mean of $i$ th genotype in $j$ th environment, $\mu$ is the grand mean, $\mathrm{a}_{i}$ is the main effect of $i$ th genotype, $\beta_{j}$ is the main effect of $j$ th environment, $j_{i j}$ is interaction between $i$ th genotype and $j$ th environment.

\section{Results and Discussion}

\subsection{The AMMI Analyses of Variance}

The AMMI analysis of variance (additive main effects) showed significant effects for genotypes, environment and the genotype by environment interaction, GEI (Table 3). This implies that different hybrids could be selected for the different agro ecological zones (Derera et al., 2008). Other studies have reported significantly different $\mathrm{G} \times \mathrm{E}$ interactions for grain yield in maize (Carson et al., 2002; Makumbi, 2005; Menkir and Ayodele, 2005). The relative magnitudes of the different sources of variation varied greatly as shown by their variance components on Table 3. The results also showed that $64.5 \%$ of the total variation was contributed by the environment and GEI were associated with $20.7 \%$ and $10.3 \%$ of the total variation respectively. The large sum of squares for environments indicated that the environments included in the study were diverse with large differences among environmental means causing most of the variation in grain yield. From this study, the use of the AMMI model was justified and it effectively partitioned the sum of squares (Mwololo et al., 2009).

Table 3. Combined analysis of variance for grain yield data in maize genotypes across three environments

\begin{tabular}{lllll}
\hline Source & df & SS & MS & Total variation (\%) \\
\hline Total & 293 & 10143 & 34.6 & \\
Treatments & 146 & 9696 & $66.4^{* * *}$ & 95.6 \\
$\quad$ Genotypes & 48 & 2096 & $43.7^{* * *}$ & 20.7 \\
$\quad$ Environments & 2 & 6552 & $3276^{* * *}$ & 64.6 \\
$\quad$ Interactions & 96 & 1049 & $10.9^{* * *}$ & 10.3 \\
IPCA & 49 & 925 & $18.9^{* * *}$ & 9.1 \\
IPCA & 47 & 123 & 2.6 & 1.2 \\
$\quad$ Residuals & 0 & 0 & & \\
Block & 3 & 121 & $40.4^{* * *}$ & 1.2 \\
Error & 144 & 325 & 2.3 & 3.2 \\
\hline
\end{tabular}

NB: The block source of variation refers to blocks within environments.

$* * *=$ significance level at $\mathrm{p}<0.001$.

\subsection{The Grain Yield Adaptability and Yield Stability}

The grain yield adaptability and yield stability of the single cross hybrids derived from the seven maize inbred lines were visually assessed using the GGE biplot analysis. In this study, the first two principal components explained a total of 78.17\% GGE variation (PC1 50.91\%, PC2 27.26\%, Figure 1, Table 4). The first principal component (PC1) represented on the $\mathrm{x}$ axis and across its value was used to estimate yield in that the genotypes which had higher PC1 values were considered to be more productive. The second principal component which 
was represented on the y axis explained the stability of genotypes (Abay et al., 2009; Muhammadi and Amri, 2009). The average environment axis (AEA) or average tester coordinate (ATC) was presented as the line which passes through the circle and the origin of the biplot. In this study, the greatest stability in the high yielding group was related to genotypes X33, X20 and X21, while the most stable of all was X20 (Figure 1 and Table 4). The genotype X20 could be used for broad selection since it was found to be the most ideal genotypes with both high mean yield and high stability. In the biplot analysis, X20 is close to the origin and has the shortest vector from the ATC implying that it has the least contribution to GEI (Muhammadi and Amri, 20009). Through the stability analysis, superior genotypes could be identified from multi location trials (Sharma et al., 2010).

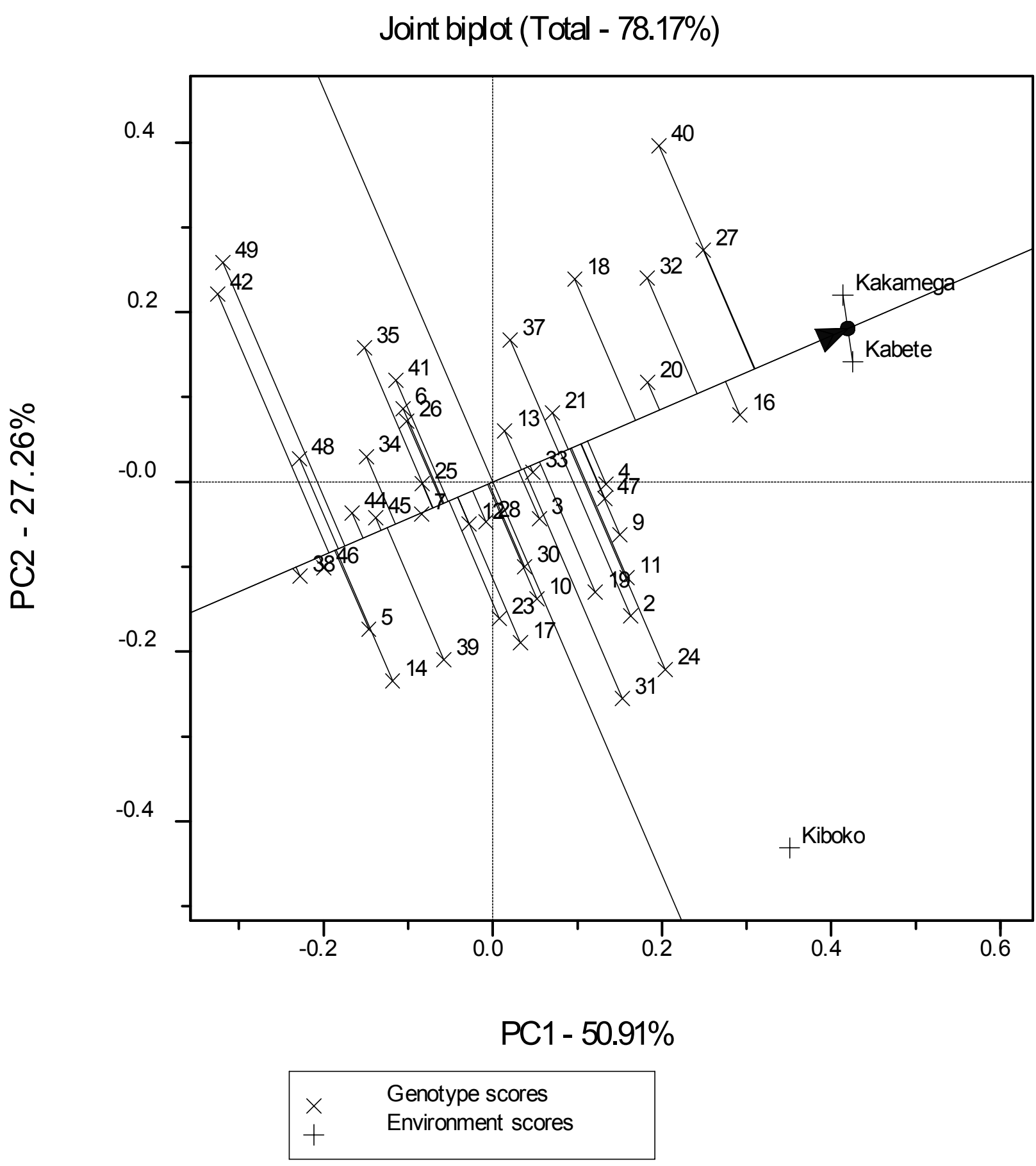

Figure 1. GGE-biplot showing ranking of 42 maize genotypes based on yield and stability performance across three environments; Kiboko, Kabete and Kakamega. Their parentage of genotypes is listed on Table 4 
Table 4. The genotypes and the parentage used in the experiment

\begin{tabular}{llll}
\hline Genotype & *Parentage & Genotype & Parentage \\
\hline X2 & CML204/CML312 & X26 & CML384/TZMI 102 \\
X3 & CML204/CML373 & X27 & CML384/TZMI 711 \\
X4 & CML204/CML384 & X28 & CML384/TZMI 712 \\
X5 & CML204/TZMI 102 & X30 & TZMI 102/CML204 \\
X6 & CML204/TZMI 711 & X31 & TZMI 102/CML373 \\
X7 & CML204/TZMI 712 & X32 & TZMI 102/CML312 \\
X9 & CML373/CML204 & X33 & TZMI 102/CML384 \\
X10 & CML373/CML312 & X34 & TZMI 102/TZMI 711 \\
X11 & CML373/CML384 & X35 & TZMI 102/TZMI 712 \\
X12 & CML373/TZMI 102 & X37 & TZMI 711/CML204 \\
X13 & CML373/TZMI 711 & X38 & TZMI 711/CML373 \\
X14 & CML373/TZMI 712 & X39 & TZMI 711/CML312 \\
X16 & CML312/CML204 & X40 & TZMI 711/CML384 \\
X17 & CML312/CML373 & X41 & TZMI 711/TZMI 102 \\
X18 & CML312/CML384 & X43 & TZMI 711/TZMI 712 \\
X19 & CML312/TZMI 102 & X44 & TZMI 712/CML204 \\
X20 & CML312/TZMI 711 & X45 & TZMI 712/CML373 \\
X21 & CML312/TZMI 712 & X46 & TZMI 712/CML312 \\
X23 & CML384/CML204 & X47 & TZMI 712/CML384 \\
X24 & CML384/CML373 & X48 & TZMI 712/TZMI 102 \\
X25 & CML384/CML312 & X49 & TZMI 712/TZMI 711 \\
\hline
\end{tabular}

*Parentage implies the inbred lines involved in the single cross hybrids.

The genotypes were also grouped into either high yielding or low yielding by the average ordinate environment (AOE) (Figure 2, Table 4) (Mohammadi \& Amri, 2009). The dotted line is a performance line which passes through the origin of the biplot and helps to determine mean performance of a genotype with the arrow on the performance line showing increasing mean grain yield performance. The highest nominal yield was attributed to genotypes X16, X24, X27, X40 and was identified as the best performers. The poorest performers included X49, X42, X17 and X14 (Figure 2 and Table 4). These genotypes are referred to as vertex genotypes characterised by having the longest distance from the origin of the biplot in their directions. From this study, genotype X27, X16 and X24 showed the best performance in KARI Kakamega, Kabete and KARI Kiboko respectively. They were also the most responsive genotypes which also showed specific adaptation (Abay et al., 2009). They show lower or decreased stability (Sharma et al., 2010). 
Scatter plot (Total - $78.17 \%$ )

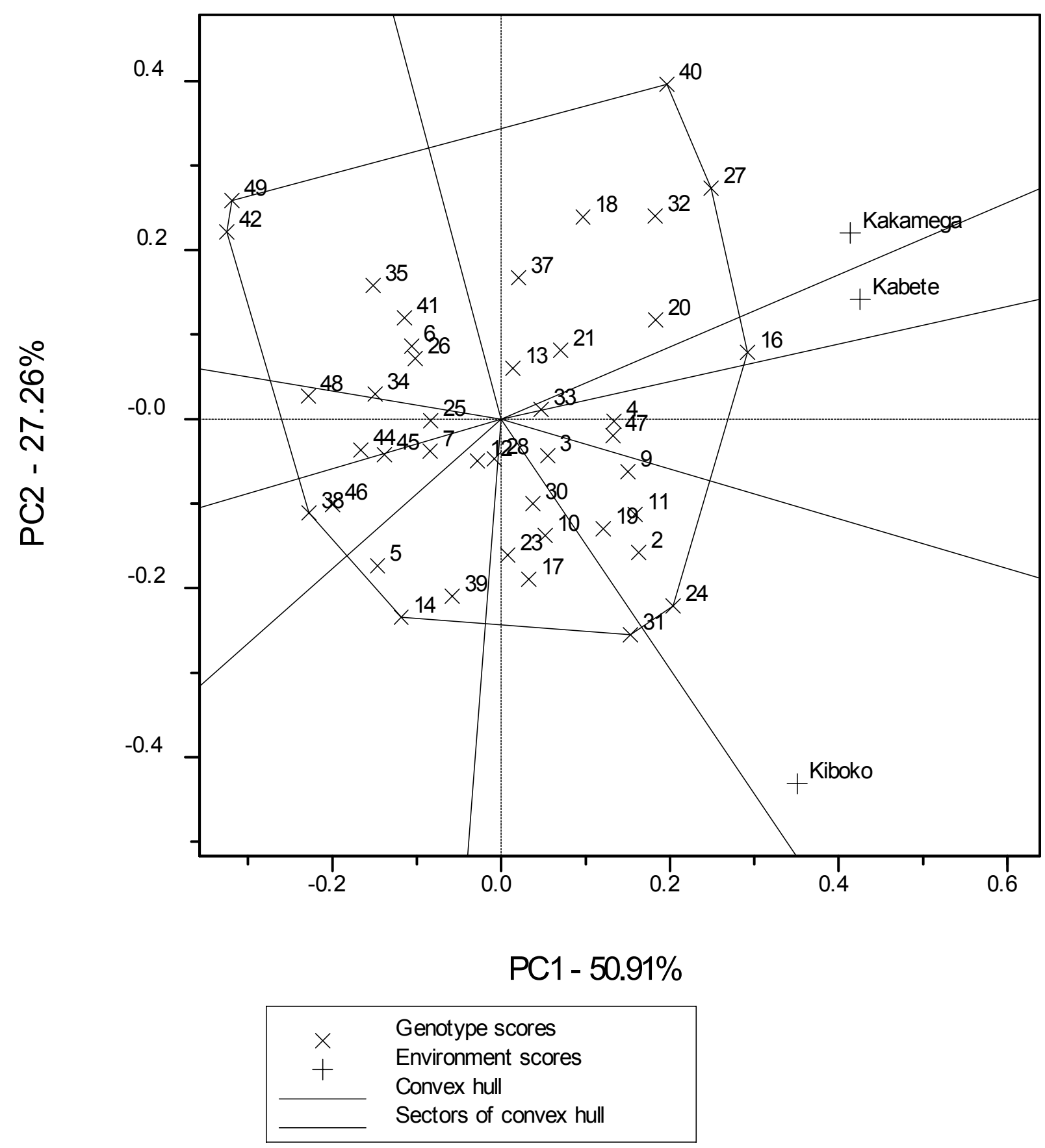

Figure 2. Polygon view of the GGE-biplot showing the mega-environments and their respective highest yielding and stable. The parentage of the genotypes is listed on Table 4

\subsection{Mean Performance and Stability of the Maize Genotypes}

Through the genotype ranking, the genotype which had the highest grain yield and absolutely stable in performance across test environments was also identified (Figure 3). The ideal genotype basically has the highest average value of all genotypes and is absolutely stable (PCA scores near zero) in that it does not exhibit any genotype by environment interaction hence broad adaptation (Yan \& Kang, 2003; Sharma et al., 2010; Akcura et al., 2011). In view of this, hybrid X20 was the most ideal genotype with large PC1 scores (high mean yield) and 
small (absolute) PC2 scores (high stability). The genotype X20 could be used as a reference for genotype evaluation (Kaya et al., 2006). It could also have the greatest commercial success because it showed the highest stability. Other desirable genotypes included X16, X32 and X27 (Figure 3 and Table 4) and this could be included in further testing in both early and later stages of selection (Mitrović et al., 2012).

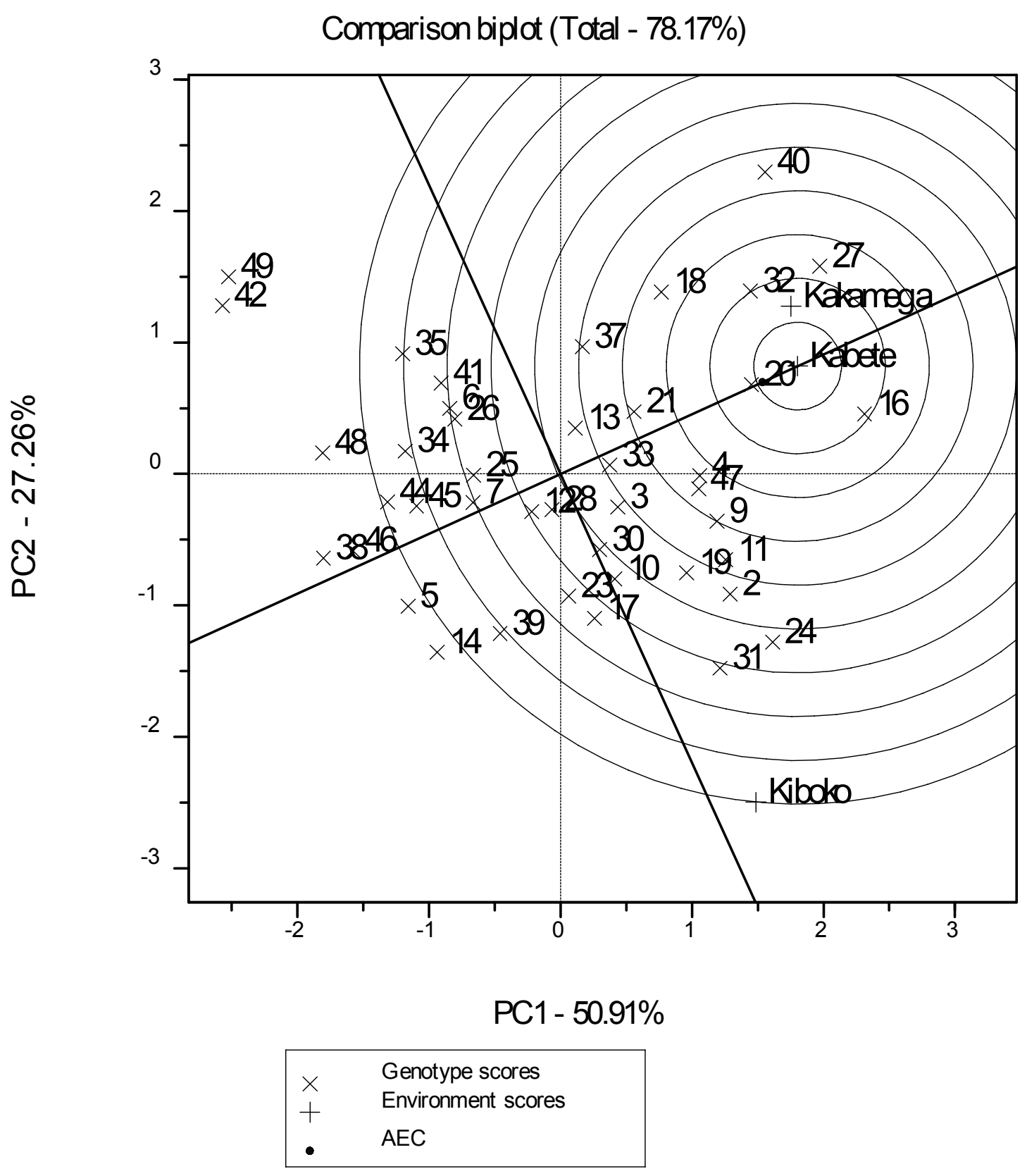

Figure 3. GGE-biplot based on genotype and environment focused scaling for comparison genotype and environments. Ranking of entries is based on both mean and stability

\subsection{Discriminating Ability and Representativeness of Test Environments}

The PC1 and PC2 were also used to obtain the ideal test environments whereby such an environment is characterised by large PC1 scores (more power to discriminate genotypes in terms of the genotypic main effect) and small (absolute) PC2 scores (more representative of the overall environments) (Yan and Rajcan, 2002). The ideal location should also have the capacity to differentiate the genotypes and representative of the target location. In this study, representativeness referred to as the average location which was used as a reference or a benchmark. 
Kabete was the most ideal environment as identified from the GGE biplot (Figure 4). The AMMI analysis also identified the best environment as Kabete which had the highest PCA1 and the best 1PCA2 values of 3.5 and -0.9 respectively (Table 5). However, high PCAs show unstable yields which could be used in the selection site for genotypes to be grown in specific environments (Akcura et al., 2011). Thus, this study identified the locations which optimized genotype selection on the basis of their discriminating ability and representativeness.

\section{Comparison biplot (Total - 78.17\%)}

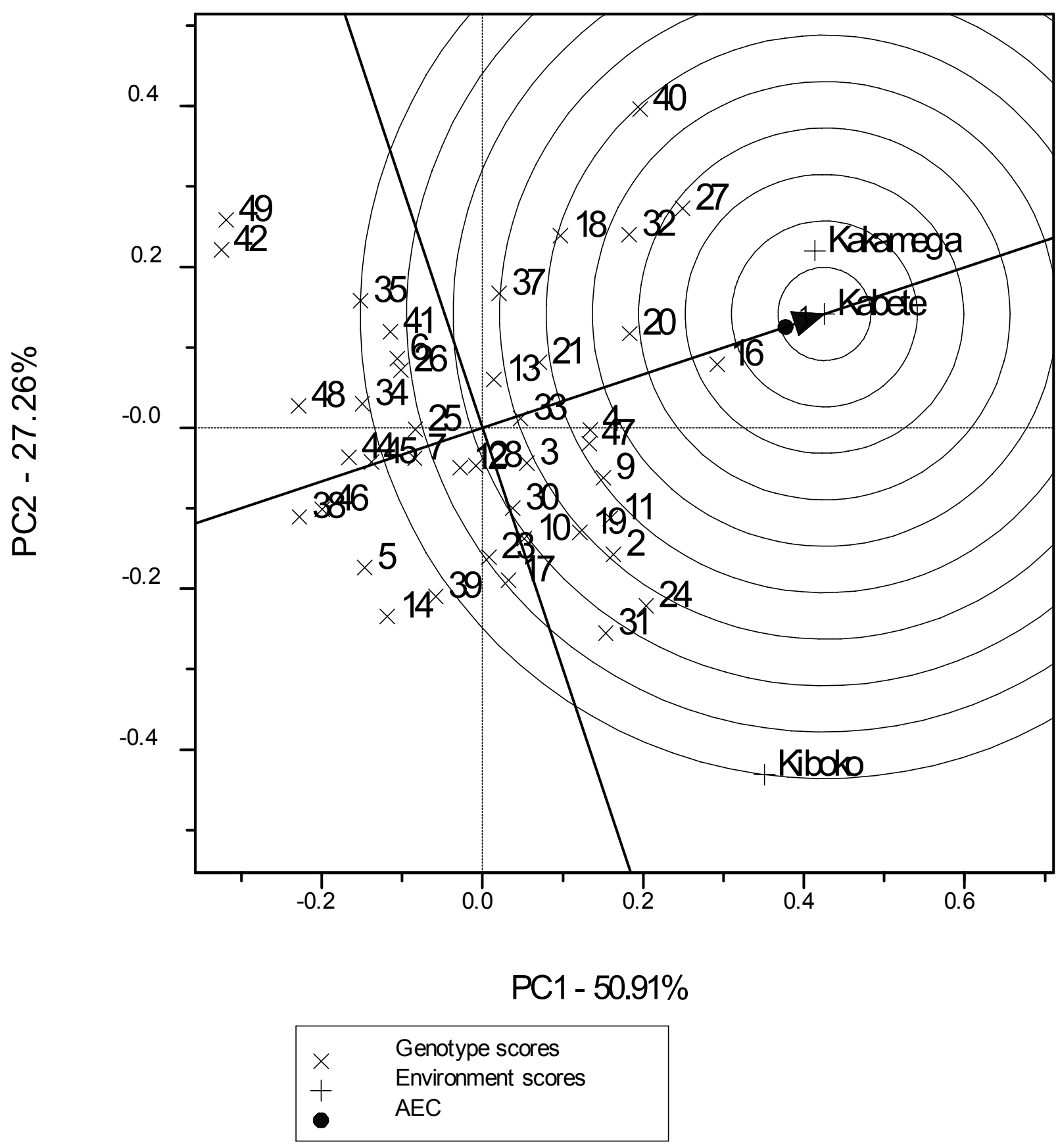

Figure 4. GGE-biplot based on genotype and environment focused scaling for comparison genotype and environments. Their parentage of the genotypes is listed on Table 4 
From the AMMI analysis, genotypes X40 and X24 performed well in two of these environments (Table 4 and Table 5). However, the differences in ranking of these genotypes in the different environments implied differential yield performance among the maize genotypes as a result of the significant genotype by environment interaction. This is also referred to as crossover GEI (Frashadfar et al., 2012). The GGE biplot and the AMMI biplot ensured environment stratification while defining cultivars which optimized performance in the environments (Miranda et al., 2009).

Table 5. Environments ranked on IPCA scores including the first four recommended genotypes for each environment based on AMMI the estimates

\begin{tabular}{lllllllll}
\hline Environment & NE & Environmental Mean & IPCAe[1] & IPCAe[2] & $1^{\text {st }}$ & $2^{\text {nd }}$ & $3^{\text {rd }}$ & $4^{\text {rd }}$ \\
\hline Kabete & 1 & 14.3 & 3.5 & -0.9 & X40 & X16 & X24 & X2 \\
KARI Kakamega & 2 & 2.8 & -3 & -1.4 & X8 & X32 & X27 & X40 \\
KARI Kiboko & 3 & 7.4 & -0.5 & 2.3 & X31 & X24 & X10 & X12 \\
\hline
\end{tabular}

The parentage of the genotypes is listed on Table 4.

\section{Conclusions and Implications}

The results of this study indicated that the maize grain yield performance was greatly influenced by the environment while the GEI contributed the least phenotypic variation. Further testing of these maize hybrids in more seasons could enhance breeding efficiency with reference to cultivar stability and adaptation across environments. Genotype X20 was the most ideal genotype followed by X16, X32 and X27. Further tests of these hybrids for commercial use could be done to enable their release given the need for increased maize production and productivity in Kenya to avert recurrent food shortages.

\section{References}

Abay, F., \& Bjørnstad, A. (2009). Specific adaptation of barley varieties in different locations in Ethiopia. Euphytica, 167, 181-195. http://dx.doi.org/10.1007/s10681-008-9858-3

Akçura, M., Taner, S., \& Kaya, Y. (2011). Evaluation of bread wheat genotypes under irrigated multi-environment conditions using GGE biplot analyses. Agriculture, 98(1), 35-40.

Beyene, Y., Mugo, S., Gakunga, J., Karaya, H., Mutinda, C., Tefera, T., ... Tende, R. (2011). Combining ability of maize Zea mays L. inbred lines resistant to stem borers. African J. Biotech, 1023, 4759-4766.

Carson, M. L., Goodman, M. M., \& Williamson, S. M. (2002). Variation in aggressiveness among isolates of Cercospora from maize as a potential cause of genotype-environment interaction in gray leaf spot trials. Plant Dis., 86, 1089-1093. http://dx.doi.org/10.1094/PDIS.2002.86.10.1089

Derera, J., Tongoona, P., Pixley, K. V., Vivek, B., Laing, M. D., \& Rij, N. C. (2008). Gene action controlling grey leaf spot resistance in Southern African maize germplasm. Crop Science, 48, 93-98. http://dx.doi.org/10.2135/cropsci2007.04.0185

Frashadfar, E., Safari, H., \& Jamshidi, B. (2012). GGE biplot analysis of adaptation in wheat substitution lines. Intl J Agri Crop Sci., 4(13), 877-881. Retrieved from www.ijagcs.com

Hill, J., Becker, H. C., \& Tigerstedt, P. M. A. (1997). Quantitative and ecological aspects of plant breeding (pp. 50- 1, 89-102 and155-173). London: Chapman and Hall.

Jong, S., \& Brewbaker, J. L. (2005). Genotype $\times$ environment interactions of maize hybrids among temperate and tropical inbreds in temporal and spatial environments. Korean Journal of Breeding, 37, 17-26.

Kaya, Y., Akcura, M., \& Taner, S. (2006). GGE-biplot analysis of multi- environment yield trials in bread wheat. Turk J. Agric. For., 30, 325-337.

Makumbi, D. (2005). Phenotypic and genotypic characterization of white maize inbreds, hybrids and synthetics under stress and non-stress environments. $\mathrm{PhD}$ dissertation Submitted to the Office of Graduate Studies of Texas A and M University

Menkir, A., \& Adepoju, M. A. (2005). Registration of 20 Tropical Mid-altitude Maize Line Sources with Resistance to Gray Leaf Spot. Crop Sci, 45, 803-804. http://dx.doi.org/10.2135/cropsci2005.0803 
Miranda, G. V., Souza, L. V., Guimarães, L. J. M., Namorato, H. L., Oliveira, R., \& Soares M. O. (2009). Multivariate analyses of genotype $\mathrm{x}$ environment interaction of popcorn. Pesq. agropec. Bras., Brasília, 44(1), 45-50

Mitrovic, B., Stanisavljevi, D., Treski, S., Stojakovic, M., Ivanovic, M., Bekavac, G., \& Rajkovic, M. (2012). Evaluation of experimental Maize hybrids tested in Multi-location trials using AMMI and GGE biplot analysis. Turkish J. of Field Crops, 17(1), 35-40.

Mohammadi, R., \& Amri, A. (2009). Analysis of Genotype $\times$ Environment Interactions for Grain Yield in Durum Wheat. Crop Sci, 49, 1177-1186. http://dx.doi.org/10.2135/cropsci2008.09.0537

Mwololo, J. K., Muturi, P. W., Mburu, M. W. K., Njeru, R. W., Kiarie, N., Munyua, J. K., ... \& Lemaga, B. (2009) Additive main effects and multiplicative interaction analysis of genotype $\mathrm{x}$ environmental interaction among sweetpotato genotypes. Journal of Animal and Plant Science, 2(3), 148-155. Retrieved from htt p://www.biosciences.elewa.org/JAPS;ISSN 2071-7024

Sharma, R. C., Morgounov, A. I., Braun, H. J., Akin, B., Keser, M., Bedoshvili, D., ... Ginkel, M. (2010). Identifying high yielding stable winter wheat genotypes for irrigated environments in Central and West Asia. Euphytica, 171, 53-64. http://dx.doi.org/10.1007/s10681-009-9992-6

Sibiya, J., Tongoona, P., Derera, J., \& Rij, N. (2012). Genetic analysis and genotype by environment (G X E) for grey leaf spot disease resistance in elite African maize (Zea mays L.) germplasm. Euphytica, 185, $349-362$. http://dx.doi.org/10.1007/s10681-011-0466-2

Vieira, R. A., Scapim, C. A., Moterle, L. M., Tessmann, D. J., Teixeira, A. A., \& Goncalves, L. S. A. (2012). The breeding possibilities and genetic parameters of maize resistance to foliar diseases. Euphytica, 185, 325-336. http://dx.doi.org/10.1007/s10681-011-0454-6

Wisser, R. J., Kolkman, J. M., Patzoldta, M. E., Holland, J. B., Yud, J., Krakowsky, M., ... Balint-Kurtie, P. J. (2011). Multivariate analysis of maize disease resistances suggests a pleiotropic genetic basis and implicates a GST gene. PNAS, 108(18), 7339-7344. http://dx.doi.org/10.1073/pnas.1011739108

Yan, W., \& Kang, M. S. (2003). GGE biplot analysis: a graphical tool for breeders, In M. S. Kang (Ed.), Geneticists, and Agronomist (pp. 63-88). Boca Raton, FL: CRC Press.

Yan, W., \& Rajcan, I. (2002). Biplot analysis of test sites and trait relations of soybean in Ontario. Crop Sci., 42, 11-20. http://dx.doi.org/10.2135/cropsci2002.0011

\section{Copyrights}

Copyright for this article is retained by the author(s), with first publication rights granted to the journal.

This is an open-access article distributed under the terms and conditions of the Creative Commons Attribution license (http://creativecommons.org/licenses/by/3.0/). 